\title{
RESEARCH ON ASSESSMENT CENTERS IN SERBIA
}

\author{
Milivoj Mrdaković, \\ Jelena Đorđević Boljanović, \\ Nemanja Stanišić \\ Singidunum University, \\ 32 Danijelova Street, Belgrade, Serbia
}

Correspondence:

Milivoj Mrdaković

e-mail:

milivoj.mrdakovic.12@singimail.rs

\begin{abstract}
:
This work represents a condensed version of extensive research conducted as part of the master's thesis work of the lead author. To the best of our knowledge, there is a general lack of research on the subject of assessment centers (ACs) not only in the Republic of Serbia but also in Southeastern and Eastern Europe. Research is being conducted in accordance with the established models and procedures in already publicized papers. We explore where the local AC practice stands compared to the developed economies as well as the developing ones. We also investigate whether there is a specific pattern of "Serbian Assessment Centers" so that we can identify and document the potentially idiosyncratic features of the local AC practice.
\end{abstract}

Key words:

selection, development, evaluation, promotion, talent management, competence.

\section{INTRODUCTION}

Assessment centers are a significant tool for assessing the future behavior of the candidate, which could be implemented for three purposes: selection of the unemployed, development of employees and promotion of employees to higher positions. The studies conducted so far have shown that there is no single purpose that is typical for all countries or companies. Despite the existence of a document entitled "Ethical Considerations and Guidelines for Assessment Center Operations"1, this survey reveals that this document is modestly used in ACs in Serbia.

Also, it is known that some countries such as the United Kingdom, Russia, Germany, Indonesia, Switzerland and South Africa have their own national standards for the implementation of practices in ACs that comply with the international guidelines interpreted within their specific national contexts.

\section{SHORT HISTORY OF ASSESSMENT CENTERS IN SERBIA}

Assessment centers first arose for military purposes in Germany in WWI and then in the United States during WWII. However, it is not a well-known fact that Serbia, despite being a state with a small population,

1 "Ethical Considerations and Guidelines for Assessment Center Operations" is a document that was created under the auspices of the American Psychological Association (APA) with the efforts of the International Task Group. 
formed its own aviation and Aerospace Command in 1912. It was the fifteenth country in the world to do so and the fifth country to use aviation in warfare.

Psychological assessment was performed in Serbia for military purposes as well. In 1931, for the first time in Serbia, the army tested the intelligence and mental functions of candidates in order to select the appropriate military pilots. ${ }^{2}$ (Стојановић, 2003)

Over time, evolution of psychological assessment took place, and it has been transformed for business purposes. Business professionals reshaped it into a modern form known as assessment centers.

As Serbia is developing and the world is globalizing, the standardization of the practice of psychological predictions for business purposes took place, in particular through the expansion of multinational corporations. At the same time, there are significant variations that are caused primarily by cultural differences.

\section{METHODOLOGY}

Following several published studies through work of Spychalski, A.C. et al (1997), Krause, E.D. et al (2003, 2009, 2011, 2012, 2014) and Tasha L.E. et al (2009), we conducted the research modelled on previous work on the territory of the Republic of Serbia to examine the state of ACs.

Previous studies have been conducted in countries whose populations are significantly larger than the population of Serbia. For example, in "Assessment center practices in Indonesia: An exploratory study" Krause E.D. et al (2014), Indonesia has a population of 254,5 million (according to the World Bank data for 2014). The USA has 316.5 million people. German-speaking European regions mentioned in Krause E.D. (2003) have a population of 97,61 million. The smallest researched state with the closest population to Serbia is South Africa, with almost 60 million people. Still, Serbia is much smaller, with population of 7,13 million.

Economically, with the exception of Indonesia and South Africa, these are developed countries, while Serbia is a developing country. The GDPs of these countries are $\$ 17,42$ trillion for the USA, $\$ 5$ trillion for Germanspeaking regions, $\$ 350,5$ billion for South Africa, and $\$ 44$ billion for Serbia. Therefore, Serbia could hardly be compared with the other countries.

Our stratified sample was completed randomly with declared professionals who work in human resources management in Serbia through LinkedIn networks, and they were individually invited to participate in the survey. 2 page 219 .
We have developed a survey that was generated through Google Forms, and we distributed links via the Internet. We invited 498 human resources professionals, 381 of whom were women and 117 men. 123 individuals completed the survey, but two were rejected because they did not work on the territory of Serbia. Thus, our final sample was $\mathbf{N}=\mathbf{1 2 1}$.

The response rate of females who completed the survey was 97 , which is $26 \%$ of those invited. The number of male respondents was 24 , which is $21 \%$ of the number of all invited. The Overall Response Rate without two rejected is $24 \%$, which we consider to be a very high percentage. The survey was conducted twelve days immediately prior to the upcoming holidays (New Year's Eve, 2016 and Orthodox Christmas), which was a pretty bad time for conducting a survey. Luckily, we had a good response.

We can conclude that professionals in human resources management showed a high level of collegiality, for which we are very grateful. We attributed such a high response to the fact that we made a personal, rather than machine-generated call to everyone individually.

\section{SOME OF THE RESULTS}

\section{Number of exercises}

Considering that this is a condensed (shortened, lighter) version of the research, we shall present some findings.

After 10 mandatory general questions, we gave an option for those who did not use AC practice in their companies. One of the optional questions was, what is the average number of exercises on assessment centers in your company? Bearing in mind that the answer depended on whether HR professionals used ACs in their practice, the number of those who responded was $\mathbf{N}=\mathbf{1 0 3}$.

Research has shown that the average number of exercises is (in percentages):

\begin{tabular}{lcc}
\hline & $\begin{array}{c}\text { Number of } \\
\text { exercises }\end{array}$ & $\%$ \\
\hline & 3 or less & 41,58 \\
& 4 to 5 & 51,49 \\
& 6 to 7 & 5,94 \\
$\begin{array}{c}\text { What is the average number } \\
\text { of exercises on the AC in your } \\
\text { company? }\end{array}$ & 8 to 9 & 0,00 \\
& $>9$ & 0,99 \\
\hline
\end{tabular}

Table 1. Average number of exercises on AC 
When we regrouped the data obtained, we noticed that $93,07 \%$ of organized assessment centers in Serbia have 5 or less exercises, and the remaining 7\% (6,93\%) have more than 5 exercises.

It was interesting for us to compare and analyze the available data from other surveys.

We compared Serbia vs. Indonesia ${ }^{3}$, Serbia vs. South Africa ${ }^{4}$ and Serbia vs. USA ${ }^{5}$ using Fisher's Exact Test and the Chi-Square Test. All $\mathrm{H}_{0}$ hypotheses were that the average number of exercises in Serbia did not deviate from the average number of exercises in other (individually paired) countries. Let's look at the following tables.

\begin{tabular}{|c|c|c|c|c|c|}
\hline & & & \multicolumn{2}{|c|}{ Country } & \multirow{2}{*}{ Total } \\
\hline & & & Serbia & Indonesia & \\
\hline \multirow{8}{*}{ 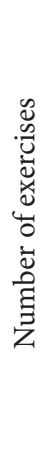 } & \multirow{2}{*}{3 or less } & Count & 42 & 26 & 68 \\
\hline & & Expected Count & 46.4 & 21.6 & 68.0 \\
\hline & \multirow{2}{*}{4 to 5} & Count & 52 & 16 & 68 \\
\hline & & Expected Count & 46.4 & 21.6 & 68.0 \\
\hline & \multirow{2}{*}{6 to 7} & Count & 6 & 5 & 11 \\
\hline & & Expected Count & 7.5 & 3.5 & 11.0 \\
\hline & \multirow{2}{*}{$\begin{array}{l}10 \text { or } \\
\text { more }\end{array}$} & Count & 1 & 0 & 1 \\
\hline & & Expected Count & .7 & .3 & 1.0 \\
\hline & \multirow{2}{*}{ Total } & Count & 101 & 47 & 148 \\
\hline & & Expected Count & 101.0 & 47.0 & 148.0 \\
\hline
\end{tabular}

Chi-Square Tests

\begin{tabular}{lcccc}
\hline & Value & df & $\begin{array}{c}\text { Asymp. Sig. } \\
(2 \text {-sided })\end{array}$ & $\begin{array}{c}\text { Exact Sig. } \\
(2 \text {-sided })\end{array}$ \\
\hline Pearson Chi-Square & $4.859^{\mathrm{a}}$ & 3 & .182 & .175 \\
\hline Likelihood Ratio & 5.180 & 3 & .159 & .161 \\
\hline Fisher's Exact Test & 4.966 & & & .135 \\
\hline N of Valid Cases & 148 & & & \\
\hline
\end{tabular}

a. 3 cells $(37,5 \%)$ have expected count less than 5 . The minimum expected count is, 32 .

Table 2. Serbia vs. Indonesia (2011)

3 (Diana E. Krause, Neil Anderson, Robert J. Rossberger, Zulaicha Parastuty, 2014), page 390

4 (Diana E. Krause, Robert J. Rossberger, Kim Dowdeswell, Nadene Venter, Tina Joubert, 2011), page 265

5 (Tasha L. Eurich, Diana E. Krause, Konstantin Cigularov, George C. Thornton III, 2009-12), page 390

\begin{tabular}{|c|c|c|c|c|c|}
\hline \multicolumn{6}{|c|}{ Number of exercises ${ }^{\star}$ Country - Crosstabulation } \\
\hline & & & \multicolumn{2}{|c|}{ Country } & \multirow{2}{*}{ Total } \\
\hline & & & Serbia & South Africa & \\
\hline \multirow{8}{*}{ 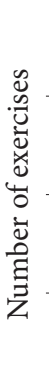 } & \multirow{2}{*}{3 or less } & Count & 42 & 18 & 60 \\
\hline & & Expected Count & 42.1 & 17.9 & 60.0 \\
\hline & \multirow{2}{*}{4 to 5} & Count & 52 & 20 & 72 \\
\hline & & Expected Count & 50.5 & 21.5 & 72.0 \\
\hline & \multirow{2}{*}{6 to 7} & Count & 6 & 5 & 11 \\
\hline & & Expected Count & 7.7 & 3.3 & 11.0 \\
\hline & \multirow{2}{*}{$\begin{array}{l}10 \text { or } \\
\text { more }\end{array}$} & Count & 1 & 0 & 1 \\
\hline & & Expected Count & .7 & .3 & 1.0 \\
\hline & \multirow{2}{*}{ Total } & Count & 101 & 43 & 144 \\
\hline & & Expected Count & 101.0 & 43.0 & 144.0 \\
\hline
\end{tabular}

Chi-Square Tests

\begin{tabular}{lcccc}
\hline & Value & df & $\begin{array}{c}\text { Asymp. Sig. } \\
(2 \text {-sided })\end{array}$ & $\begin{array}{c}\text { Exact Sig. } \\
(2 \text {-sided })\end{array}$ \\
\hline Pearson Chi-Square & $1.853^{\mathrm{a}}$ & 3 & .604 & .651 \\
\hline Likelihood Ratio & 2.045 & 3 & .563 & .651 \\
\hline Fisher's Exact Test & 1.960 & & & .623 \\
\hline
\end{tabular}

$\mathrm{N}$ of Valid Cases $\quad 144$

a. 3 cells $(37,5 \%)$ have expected count less than 5 . The minimum expected count is, 30 .

Table 3. Serbia vs. South Africa (2014)

Number of exercises ${ }^{\star}$ Country - Crosstabulation

\begin{tabular}{|c|c|c|c|c|c|}
\hline & & & & ountry & Tatol \\
\hline & & & Serbia & USA & \\
\hline & 3 orlecs & Count & 42 & 7 & 49 \\
\hline & 3 Or IESS & Expected Count & 32.3 & 16.7 & 49.0 \\
\hline & & Count & 52 & 33 & 85 \\
\hline$\stackrel{n}{0}$ & 4 to 5 & Expected Count & 56.1 & 28.9 & 85.0 \\
\hline$\stackrel{\ddot{凶}}{4}$ & & Count & 6 & 8 & 14 \\
\hline$\ddot{0}$ & 6 to 7 & Expected Count & 9.2 & 4.8 & 14.0 \\
\hline है & & Count & 0 & 4 & 4 \\
\hline $\bar{z}$ & 8 to 9 & Expected Count & 2.6 & 1.4 & 4.0 \\
\hline & 10 or & Count & 1 & 0 & 1 \\
\hline & more & Expected Count & .7 & .3 & 1.0 \\
\hline & Tatol & Count & 101 & 52 & 153 \\
\hline & lotal & Expected Count & 101.0 & 52.0 & 153.0 \\
\hline & & Chi-Squar & Tests & & \\
\hline & & Value & $\mathrm{df}$ & $\begin{array}{l}\text { Asymp. Sig. } \\
\text { (2-sided) }\end{array}$ & $\begin{array}{l}\text { Exact Sig. } \\
\text { (2-sided })\end{array}$ \\
\hline Pears & on Chi-Squ & lare $20.993^{\mathrm{a}}$ & 4 & .000 & .000 \\
\hline Likel & hood Ratio & 23.266 & 4 & .000 & .000 \\
\hline Fishe & r's Exact Te & 20.795 & & & .000 \\
\hline $\mathrm{N}$ of & Valid Cases & 153 & & & \\
\hline $\begin{array}{r}\text { a. } 5 \mathrm{c} \\
\mathrm{exp}\end{array}$ & $\begin{array}{l}\text { ells (50,0\%) } \\
\text { pected coun }\end{array}$ & $\begin{array}{l}\text { have expected co } \\
\text { th is }, 34 \text {. }\end{array}$ & unt less $\mathrm{t}$ & than 5. The & minimum \\
\hline
\end{tabular}

Table 4. Serbia vs. USA (2009) 
If we analyze the data and test values in the tables (2,3 and 4), we can conclude that there is no significant difference in the number of exercises between Serbia and Indonesia (2011) and Serbia and South Africa (2014). In fact, the data confirmed the null hypothesis.

We can also see that the $\mathbf{p}=\mathbf{0 , 6 2 3}$ value (in table 3 ) is greater than $\mathbf{p}=\mathbf{0 , 1 3 5}$ (in table 2), so there is stronger evidence that the similarity between the number of exercises on the AC in Serbia and South Africa is closer.

What differs significantly is the number of exercises in Serbia than in the USA. We have $\mathbf{p}=\mathbf{0 , 0 0 0}$, so there is strong evidence that an alternative hypothesis is correct: The number of exercises in Serbia and the number of exercises in the USA differ significantly.

However, it should be noted that there is a relatively significant time lag (seven years) between the papers from which we used the mentioned data. The differences in the studies are dispersed through years and are reduced over time, so there is an inverse proportionality. The closer cited facts from already published papers are to the immediate present, the smaller the difference.

\section{Number of assessors}

Research has shown that ACs in Serbia usually have one or two evaluators (assessors) (44.66\%) (Figure 1).

International Assessment Center Guidelines (IACG) ${ }^{6}$ says: "Multiple assessors must be used to observe and evaluate each assessee... When selecting assessors...must strive to have diverse...in terms of demographics (e.g., race, ethnicity, age, sex) and experience (e.g.,organizational level, functional work area, managers, psychologists, etc.).

The maximum ratio of assessees to assessors depends on the type of exercises used, the behavioral constructs to be evaluated, the roles of the assessors, and the type of data integration...

The ratio of assessees to assessors should be minimized where practicable... to minimize potential bias..."

It is obvious that what IACG says and practices regarding the number of assessors in Serbia are not even similar. Indeed, the "Guidelines" don't mention a clear number of assessors in its description of the requirements to this issue, but it is certainly less than the following recommendations contain.

Also, research has shown that about one-third (32.04\%) of Serbian assessment centers have three assessors, and about a quarter (23.30\%) more than three.

6 (International Taskforce on Assessment Center Guidelines, 2015), page 9

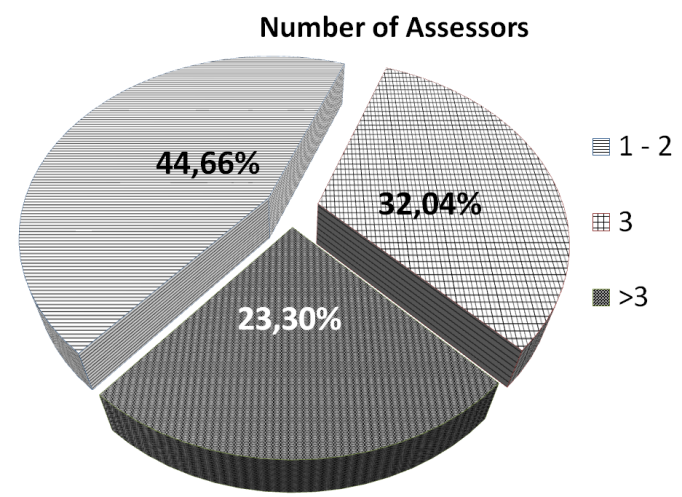

Figure 1.

We asked whether there was a connection between the number of observers and the average number of exercises.

Our $\mathrm{H}_{0}$ (null hypothesis) was: "The average number of exercises is independent of the number of assessors."

We got the strong evidence where $p<0.01$, confirmed that our alternative hypothesis, $\mathrm{H}_{1}$ - “The average number of exercises is directly dependent on the number of assessors"-was true. Therefore, how to increase the number of assessors of ACs, increases the number of exercises (and vice versa). See Table 5.

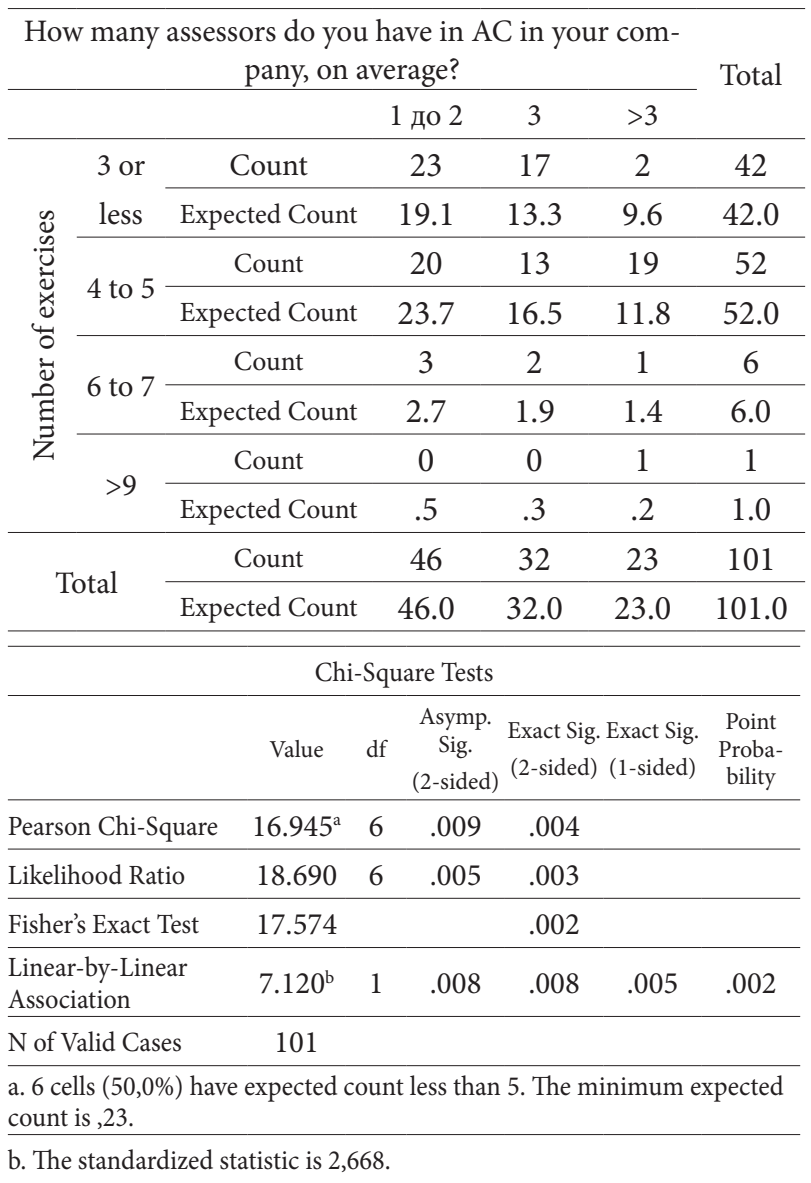

Table 5. Number of exercises ${ }^{\star}$ Number of assessors Crosstabulation 


\section{DISCUSSION}

Conclusions from this study should be interpreted with certain limitations in mind.

First, the data collected in Serbia (2016) and the data collected in other studies have significant time gaps that could be seen as potential problems. In emerging economies, there is rapid change. There are indications that changes in the development of AC were significant. To quote the study by Diana E. Krause and Diether Gebert, "There are indications that the execution of ACs in the United States may have changed in the meantime because the number of exercises and assessment days have been reduced" (Krause, Diana E., and Diether Gebert, 2003) ${ }^{7}$. We should assume that something similar happened with the surveys whose data was used in this work.

Very important limitation of this study was the "randomness" of the sample of the population that cannot claim to be representative for sure. Not all HR professionals have LinkedIn profiles.

Third, the study was methodologically limited to the quantitative research, and there was no consideration of qualitative analysis of ACs in Serbia. The next qualitative analysis should include the qualified number of HR experts who were not available for the survey at the time.

The fourth possible shortage is objective in its nature, since Serbia is a small country with limited population, especially compared to large countries like the United States, Indonesia, Germany and others. However, we had an excellent response that increased the accuracy and representativeness of the results. Maybe the proposed future research that would include the whole region of Southeast Europe could obtain more representative results.

Finally, it should be emphasized that our intention was to gain insight into the contemporary Serbian practice of ACs, in which it was necessary to have generality since there were no similar studies. In other words, this study tried to make up for the lack of information on AC practices in Serbia in the absence of other studies.

\section{CONCLUSION}

To the authors' best knowledge, this first study of assessment centers in Serbia and our findings reveal several interesting differences (and similarities) between AC practices in the world according to the available data. In this paper, we may have exposed a small number of very interesting facts about AC practices in Serbia.

7 p. 309
The fact that ACs have their own clearly defined and internationally accepted standards and structure led us to the conclusion that there are cultural and other differences caused by the traditional standards and modalities of psychological evaluation in Serbia compared to "Guidelines."

For the sake of harmonization, it could be necessary to establish the National Congress of Assessment Center Developers and National Guidelines for the Development of AC that could lead and standardize practices of ACs, thus raising the quality criteria, ethical standards and principles.

Future research of ACs in Serbia should also have a qualitative character. Perhaps there could be a regional survey to understand the state of practice of Assessment Centers in this part of Southeast Europe.

\section{REFERENCES}

British Psychological Society . (n.d.). Design, Implementation and Evaluation of Assessment and development centres: Best Practice Guidelines. PTC12/10.05.

British Psychological Society. (2015). The Design and Delivery of Assessment Centres. INF234 .

Dessler, G. (2013, 2011, 2008, 2005, 2003). Human Resource Management 13th Edition. New Jersey, USA: Pearson Education, Inc. publishing as Prentice Hall.

Diana E. Krause \& George C Thornton III. (2009). A Cross-Cultural Look at Assessment Center Practices: Survey Results from Western Eurpe and North America. Applied Psychology 58(4), 557-585.

Diana E. Krause. (2012). Staffing and Developing Personnel Using Assessment Centers: Evidence from Three Continents. GTSF International Joural of Law and Social Sciences v2 no.1., 20-30.

Diana E. Krause, Robert J. Rossberger, Kim Dowdeswell, Nadene Venter, Tina Joubert. (2011). Assessment Center Practices in South Africa. International Journal of Selection and Assessment v. 19, 262-275.

Division of Labor Force Statistics. (2016, February 10). Labor Force Statistics from the Current Population Survey. Retrieved February 21, 2016, from U.S. Bureau of Labor Statistics: http://www.bls.gov/cps/cpsaat11.htm

Edenborough, R. (2005). Assessment Methods in Recruitment, Selection \& Performance. London : Kogan Page.

Employee selection. (2016). Retrieved January 7th, 2016, from http://www.businessdictionary.com/: http:// www.businessdictionary.com/definition/employeeselection.html

George C. Thornton III, Deborah E. Rupp. (2006). Assessment Centers in Human Resource Management. Mahwah, New Jersey: Lawrence Erlbaum Associates. 
International Taskforce on Assessment Center Guidelines. (2015). Guidelines and Ethical Considerations for Assessment Center Operations. Journal of Management, 1244-1273.

Krause, D. E. (2012). Staffing and Developing Personnel Using Assessment Centers: Evidence from Three Continents. GSTF Journal of Law and Social Sciences (JLSS), 2(1), 112-117.

Krause, Diana E., and Diether Gebert. (2003). A Comparison of Assessment Center Practices in Organizations in German-speaking Regions and the United States. International Journal of Selection and Assessment 11.4, 297-312.

Krause, Diana E.Neil Anderson, Robert J. Rossberger, Zulaicha Parastuty. (2014). Assessment center practices in Indonesia: An exploratory study. International Journal of Selection and Assessment v22, 384-398.

MacKinnon, D. W. (1980). How assessment centers were started in the United States: The OSS assessment program. Development Dimensions International.

Pulakos, E. D. (2005). Selection assessment methods: A guide to implementing formal assessments to build a high-quality workforce. SHRM Foundations.

Robert D. Gatewood, Hubert S. Feild, Murray R. Barrick. (2016, 2011). Human Resource Selection 8th Edition. Boston, MA 02210, USA: Cengage Learning, Channel Center Street.

SHRM. (2009). SHRM ${ }^{\circledR}$ Human Capital Benchmarking Study, 2009 Executive Summary. Alexandria, VA 22314, USA: Society for Human Resource Management.

Spector, P. E. (2012, 2008, 2006, 2003). Industrial and organizational psychology: research and practice - 6 th $e d$. New Jersey: John Wiley \& Sons, Inc.
Spychalski, A. C., Quinones, M. A., Gaugler, B. B., \& Pohley, K. . (1997). A survey of assessment center practices in organizations in the United States. Personnel Psychology, 50(1), 71-90.

Tasha L. Eurich, Diana E. Krause, Konstantin Cigularov, George C. Thornton III. (2009). Assessment Centers: Current Practices in the United States. Journal of Business and Psychology, Volume 24, Issue 4, pp 387-407.

Tuna, C. (2008, October 23). Even in HR, Women's Pay Lags Men's. Retrieved february 21, 2016, from The Wall Street Journal: http://www.wsj.com/articles/ SB122462820367156127

Јелена Ђорђевић Бољановић, Жарко С. Павић. (2011). Основе менаимента тьудких ресурса. Београд: Универзитет Сингидунум.

Јелена Ђорђевић Бољановић, Лазар Дражета, Лепа Бабић, Гордана Добријевић. (2013). Развој каријере и пословних вештина. Београд: Универзитет Сингидунум.

Миљевић, П. д. (2007). Методологија научног рада скрипта. Пале: Филозофски факултет, Универзитет у источном Сарајеву.

Стојановић, М. (2003). Педесет година друштва психолога Србије 1953-2003. Београд: Центар за примењену психологију Друштва психолога Србије.

Федерация оценки персонала НК РЧК (Personnel Assessment Federation of NC HCD Task Force). (2014). Российский стандарт Центра оценки (Russian Standard for Assessment Center). Москва: Федерация оценки персонала НК РЧК. 